\title{
CHEMICAL ANALYSIS AND ANTIOXIDANT ACTIVITY OF SOME ROOIBOS TEA PRODUCTS
}

\author{
ALEXANDRA EPURE $^{1 *}$, ILIOARA ONIGA ${ }^{1 *}$, DANIELA BENEDEC $^{1 *}{ }^{1 \#}$, DANIELA HANGANU ${ }^{1}$, \\ ANA-MARIA GHELDIU ${ }^{2 \#}$, ANCA TOIU ${ }^{1}$, LAURIAN VLASE ${ }^{2}$ \\ ${ }^{1}$ Department of Pharmacognosy, Faculty of Pharmacy, "Iuliu Hațieganu” University of Medicine and Pharmacy, 8 V. Babeș \\ Street, Cluj-Napoca, Romania \\ ${ }^{2}$ Department of Pharmaceutical Technology and Biopharmacy, "Iuliu Hațieganu” University of Medicine and Pharmacy, 8 \\ V. Babeș Street, Cluj-Napoca, Romania
}

*corresponding author: ioniga@umfcluj.ro

${ }^{\#}$ Authors with equal contribution

Manuscript received: April 2019

\begin{abstract}
The Rooibos tea, known as well as red tea, has lately gain attention due to its reported rich antioxidant composition. The aim of this research was to determine the polyphenol content and antioxidant capacity of 6 commercial types of Rooibos tea available on the Romanian market. The analyses of polyphenolic compounds were carried out using chromatographic and spectrophotometric methods. The total polyphenol content (TPC) was assessed by the Folin-Ciocâlteu method and some polyphenols were identified by HPLC: ferulic, sinapic acids, hyperoside, isoquercitrin, rutin, quercitrin, quercetin, luteolin, kaempferol etc. The results showed qualitative and quantitative differences between the samples. The evaluation of antioxidant capacity was performed using DPPH ( $\alpha, \alpha$-diphenyl- $\beta$-picrylhydrazyl) and FRAP (ferric reducing antioxidant power) methods, and a moderate activity has been highlighted for all the analysed samples.
\end{abstract}

\section{Rezumat}

Ceaiul de Rooibos, care mai este denumit ceai roșu, a devenit cunoscut prin compoziția bogată în principii active antioxidante. Studiul a avut ca scop determinarea conținutului în polifenoli și a capacități antioxidante a 6 sortimente de ceaiuri de Rooibos existente pe piaţa românească. Analiza polifenolilor s-a realizat prin metode cromatografice şi spectrofotometrice. Conținutul de polifenoli totali a fost evaluat prin metoda Folin-Ciocâlteu, iar prin HPLC s-au identificat compuși polifenolici: acid ferulic, acid sinapic, hiperozida, izoquercitrina, rutozida, quercitrina, quercetin, luteolina, kempferolul etc. Rezultatele au arătat diferențe calitative și cantitative între probe. Evaluarea capacității antioxidante s-a realizat prin metodele DPPH şi FRAP, toate probele analizate având o activitate moderată.

Keywords: Aspalathus linearis, Rooibos, polyphenols, antioxidant capacity

\section{Introduction}

Aspalathus linearis (Fabaceae family) is a plant species from South Africa which grows annually, spontaneous in a limited region of the Cederberg Mountains [6]. The plant exists in different ecotypes, the most common being the shrub [5]. The plant is utilized in traditional medicine as a relaxing drink due to its caffeine free and low tannin composition [6]. A. linearis tea became known as a healthy drink after the success in the treatment of chronic restlessness, in a colicky baby by administration of Rooibos tea infusion. The parts of the plant that present pharmacognostic value are the leaves and the aerial parts: Aspalathi folium and Aspalathi herba [8]. A. linearis plant can be found in spontaneous flora as well as in cultures of medicinal plants for commercial purposes. The Rockland variety is cultivated and harvested to produce the wellknown Rooibos tea [7]. There are two commercial sorts of Rooibos tea: Green Rooibos - unfermented tea; Red Rooibos - fermented tea (obtained from the plant after the fermentation process) [2]. Nowadays, studies of Aspalathus linearis reveal its composition in polyphenols (dihidrochalcones: aspalathin, nothofagin; free flavones and glycosides: orientin, iso-orientin, vitexin, isovitexin, luteolin, luteolin-7- $O-\beta-\mathrm{D}$-glucoside; free flavonols and glycosides: quercetin, hyperoside, rutin; tannins) [5, 6]. Accordingly, the aim of this research was to analyse the bioactive compounds of $A$. linearis from 6 herbal teas available on the Romanian market, in order to evaluate the quality of the commercial products.

\section{Materials and Methods}

Plant material: 6 assortments of teas containing fermented Rooibos as a single plant were purchased from the Romanian market (manufacturers: AdNatura SRL, Celmar Trading SRL, Demmers Teehaus, 
Laboratoarele Fares Bio Vital SRL, SC Sonnentor SRL, English Tea Shop UK).

Extraction procedure: the extracts were obtained from $5 \mathrm{~g}$ Rooibos tea (extracted in advanced with dichloromethane in Soxhlet) and $50 \mathrm{~mL} 70 \%$ methanol, for 30 minutes at $60^{\circ} \mathrm{C}$ [11-13].

The total polyphenol content (TPC) was determined spectrophotometrically, by Folin-Ciocâlteu method. TPC was expressed as g gallic acid equivalents (GAE)/ $100 \mathrm{~g}$ dry material plant $[1,12]$.

The total flavonoid content (TFC) was determined spectrophotometrically, using $\mathrm{AlCl}_{3}$ as a colour reagent. The results were expressed as $\mathrm{g}$ rutin equivalents $\mathrm{RE} / 100 \mathrm{~g}$ dry plant material $[1,12]$.

The DPPH method. The stable DPPH. was used to evaluate the free radical scavenging activity of the Rooibos extracts. The results were also defined as inhibitory concentration $\mathrm{IC}_{50}$. Trolox was used as a reference. The calibration curve was plotted using concentrations in the range of $5-25 \mu \mathrm{g} / \mathrm{mL}$ Trolox $\left(\mathrm{y}=2.848 \mathrm{x}+18.08 ; \mathrm{R}^{2}=0.997\right)[1,3,15]$.

The FRAP method. This method evaluated the reduction of the iron, which is reduced from the ferric ion to the ferrous ion in a complex of iron with the radical 2,4,6-tripyridyl-s-triazine [3, 14]. Results are expressed as $\mathrm{mM}$ Trolox equivalents/100 $\mathrm{mL}$ extract, using a calibration curve $\left(\mathrm{R}^{2}=0.989\right)$ constructed with 10 $40 \mathrm{mg} / \mathrm{L}$ Trolox standard.

All the quantitative determinations were realized in triplicate.

HPLC analysis of polyphenolic compounds was undertaken using an Agilent 1100 HPLC Series system equipped with degasser, binary gradient pump, column thermostat, autosampler. The HPLC system was coupled with an Agilent 1100 mass spectrometer (LC/MSD

Ion Trap SL). The analysis was performed using the conditions previously described [1, 3, 4, 9, 11, 13, 15]. The polyphenol-carboxylic acids were UV detected at $330 \mathrm{~nm}$, and the flavonoids at $370 \mathrm{~nm}$. The polyphenolic compounds of the methanolic extracts were identified based on their retention time and MS spectra compared to the standards. Twelve polyphenolic compounds (chlorogenic acid, $p$-coumaric acid, ferulic acid, sinapic acid, hyperoside, isoquercitrin, rutin, quercitrin, quercetin, luteolin, kaempferol, apigenin) were used as standards. Calibration curves in the $0.5-50 \mu \mathrm{L} / \mathrm{mL}$ concentration range $\left(\mathrm{R}^{2}>0.999\right)$ were used.

\section{Results and Discussion}

The results obtained for TPC, TFC and the antioxidant capacity of the six analysed samples are listed in Table I.

The TPC of the Rooibos tea has been reported in the literature in the range of 7.9 - $9.3 \mathrm{~g} \mathrm{GAE} / 100 \mathrm{~g}$ [10]. In our experiment, the values of TPC were between 4.3 - 6.8 g GAE/100 g. Samples 6 and 3 present higher TPC $(6.79 \pm 0.33$ and $6.07 \pm 0.30 \mathrm{~g} \mathrm{GAE} /$ $100 \mathrm{~g}$ ), comparable with the current data available. Samples 4 and 5 are next in line with a moderate $\mathrm{TPC}(5.46 \pm 0.27 ; 5.76 \pm 0.28 \mathrm{~g} \mathrm{GAE} / 100 \mathrm{~g})$ followed by samples 1 and $2(4.3 \pm 0.21$ and $2.97 \pm$ $0.14 \mathrm{~g} \mathrm{GAE} / 100 \mathrm{~g}$ ).

The content of flavonoids increases in the order: sample $2<1<4<3$, with higher concentrations in the samples 6 and $5(1.16 \pm 0.05$ and $1.10 \pm 0.05 \mathrm{~g}$ $\mathrm{RE} / 100 \mathrm{~g})$. The flavonoid levels in the Rooibos samples are lower than the values reported by other authors from South Africa (2.94\%) [6].

Table I

Composition and codification of metronidazole gel formulations

\begin{tabular}{|l|c|c|c|c|}
\hline Aspalathus samples & $\begin{array}{c}\text { TPC } \\
(\mathbf{g ~ G A E} / \mathbf{1 0 0} \mathbf{g})\end{array}$ & $\begin{array}{c}\text { Flavonoids } \\
(\mathbf{g} \text { RE/100 g) }\end{array}$ & $\begin{array}{c}\mathbf{I C}_{\mathbf{5 0}} \text { value } \\
(\boldsymbol{\mu g} / \mathbf{m L})\end{array}$ & $\begin{array}{c}\text { FRAP } \\
(\boldsymbol{\mu M} \text { TE/ 100 } \mathbf{~ m L} \text { extract })\end{array}$ \\
\hline Sample 1 & $4.30 \pm 0.21$ & $0.561 \pm 0.02$ & $69.547 \pm 2.78$ & $1791.28 \pm 15.72$ \\
\hline Sample 2 & $2.97 \pm 0.14$ & $0.460 \pm 0.02$ & $106.763 \pm 4.27$ & $1239.42 \pm 10.58$ \\
\hline Sample 3 & $6.07 \pm 0.30$ & $0.836 \pm 0.04$ & $62.547 \pm 2.50$ & $2336.10 \pm 11.9$ \\
\hline Sample 4 & $5.46 \pm 0.27$ & $0.704 \pm 0.03$ & $63.794 \pm 2.55$ & $1846.88 \pm 9.12$ \\
\hline Sample 5 & $5.76 \pm 0.28$ & $1.100 \pm 0.05$ & $69.151 \pm 4.36$ & $3042.32 \pm 11.68$ \\
\hline Sample 6 & $6.79 \pm 0.33$ & $1.169 \pm 0.05$ & $56.431 \pm 2.25$ & $3153.94 \pm 10.06$ \\
\hline Trolox & - & - & $11.20 \pm 0.09$ & - \\
\hline
\end{tabular}

Values are expressed as mean \pm SD $(n=3)$.

The antioxidant capacity of these extracts was determined by two methods: DPPH bleaching assay and the ferric reducing antioxidant power assay (FRAP). The antioxidant capacity of the six Rooibos extracts was investigated using the DPPH radical scavenging assay. The results showed moderate values of the antioxidant capacity for samples $1,3,4,5,6$, with $\mathrm{IC}_{50}<100$, compared to Trolox $\left(\mathrm{IC}_{50}=11.20 \mu \mathrm{g} / \mathrm{mL}\right.$ ). The greater antioxidant capacity had the sample 6 , $\left(\mathrm{IC}_{50}=56.43 \mu \mathrm{g} / \mathrm{mL}\right)$. Our results were better than the reported value for African Rooibos $\left(\mathrm{IC}_{50}=83.4\right.$ $\mu \mathrm{g} / \mathrm{mL}$ ) [6]. The antioxidant activity performances order by FRAP test (expressed as $\mu \mathrm{M}$ Trolox equivalents $/ 100 \mathrm{~mL}$ extract) for the six methanolic extracts was as follows: $6>5>3>4>1>2$. The sample 6 showed the higher antioxidant capacity both by the FRAP and DPPH methods.

By HPLC analyses, some polyphenols were identified and quantified (Table II, Figures 1, 2 and 3). 
Phenolic compounds in the analysed samples (mg/100 g plant material)

\begin{tabular}{|l|c|c|c|c|c|c|c|}
\hline \multicolumn{1}{|c|}{ Compound } & RT \pm SD & Sample 1 & Sample 2 & Sample 3 & Sample 4 & Sample 5 & Sample 6 \\
\hline chlorogenic acid & $5.60 \pm 0.11$ & $3.34 \pm 0.06$ & - & - & - & - & - \\
\hline$p$-coumaric acid & $8.70 \pm 0.17$ & $0.80 \pm 0.01$ & - & $1.34 \pm 0.02$ & - & - & - \\
\hline ferulic acid & $12.20 \pm 0.24$ & $6.22 \pm 0.12$ & $0.98 \pm 0.01$ & $8.39 \pm 0.16$ & $1.58 \pm 0.03$ & $0.86 \pm 0.01$ & $1.28 \pm 0.02$ \\
\hline sinapic acid & $14.30 \pm 0.28$ & $6.64 \pm 0.13$ & $7.43 \pm 0.14$ & $6.96 \pm 0.13$ & $12.43 \pm 0.24$ & $6.27 \pm 0.12$ & $14.71 \pm 0.29$ \\
\hline hyperoside & $18.60 \pm 0.37$ & $15.43 \pm 0.30$ & $6.26 \pm 0.12$ & $7.76 \pm 0.15$ & $20.28 \pm 0.40$ & $6.96 \pm 0.13$ & $7.12 \pm 0.14$ \\
\hline isoquercitrin & $19.60 \pm 0.39$ & - & $10.97 \pm 0.21$ & - & $13.05 \pm 0.26$ & $6.41 \pm 0.12$ & $14.81 \pm 0.29$ \\
\hline rutin & $20.20 \pm 0.40$ & $14.51 \pm 0.29$ & - & $4.27 \pm 0.08$ & - & - & - \\
\hline quercitrin & $23.04 \pm 0.40$ & - & $4.42 \pm 0.08$ & - & $5.31 \pm 0.10$ & $1.89 \pm 0.03$ & $6.94 \pm 0.13$ \\
\hline quercetin & $26.80 \pm 0.53$ & $19.05 \pm 0.38$ & - & $101.42 \pm 2.02$ & - & - & - \\
\hline luteolin & $29.14 \pm 0.58$ & $9.11 \pm 0.18$ & $23.07 \pm 0.46$ & $12.91 \pm 0.25$ & $14.54 \pm 0.29$ & $14.70 \pm 0.29$ & $27.48 \pm 0.54$ \\
\hline kaempferol & $31.6 \pm 0.63$ & - & $9.179 \pm 0.18$ & $0.74 \pm 0.01$ & $6.27 \pm 0.12$ & $10.56 \pm 0.21$ & $12.77 \pm 0.25$ \\
\hline apigenin & $33.10 \pm 0.66$ & $0.87 \pm 0.01$ & - & $2.34 \pm 0.04$ & - & $1.16 \pm 0.02$ & - \\
\hline
\end{tabular}

Values are expressed as mean \pm SD $(n=3)$.
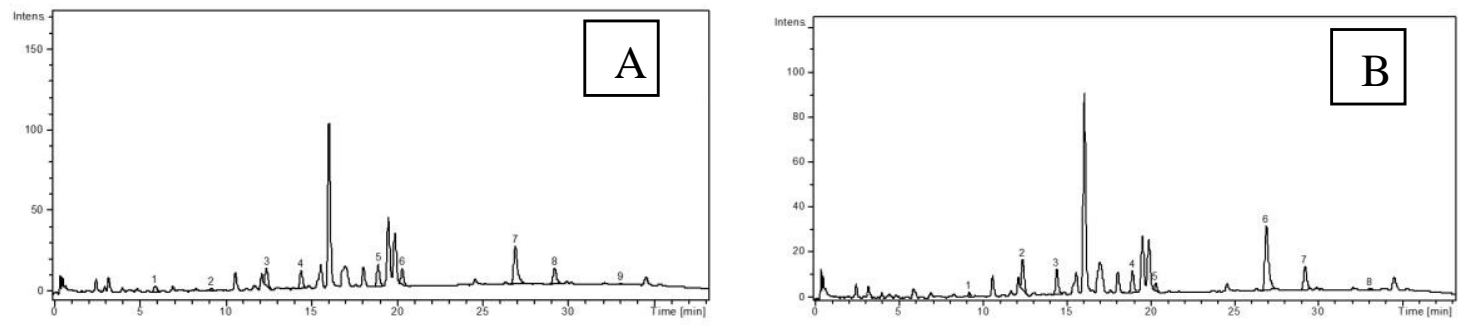

Figure 1.

HPLC chromatograms of sample 1 (A) and sample 2 (B)
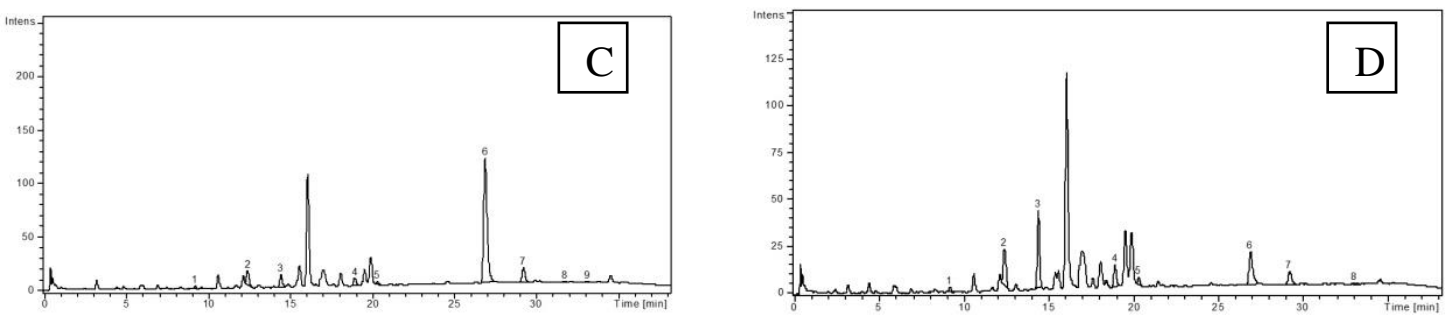

Figure 2.

HPLC chromatograms of sample 3 (C) and sample 4 (D)
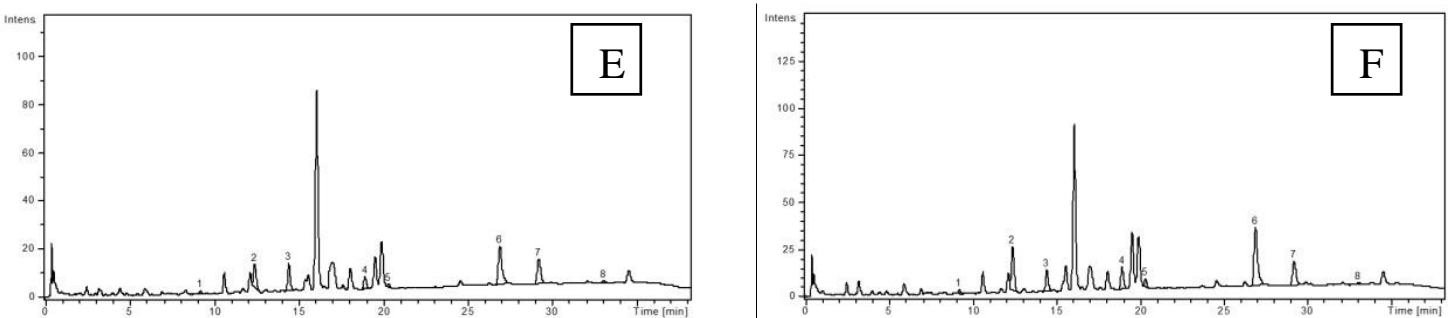

Figure 3.

HPLC chromatograms of sample $5(\mathrm{E})$ and sample $6(\mathrm{~F})$

The polyphenolic acids identified and quantified in our samples are: chlorogenic, $p$-coumaric, ferulic and sinapic acids. The ferulic and sinapic acids were identified and quantified in all six samples, with high levels for ferulic acid in Sample $3(8.39 \mathrm{mg} /$ $100 \mathrm{~g})$ and sinapic acid in Sample 6 (14.71 mg/100 g). $p$-Coumaric acid was identified and quantified in Samples 1 and 3 presenting a higher value in Sample 3 (1.34 mg/100 g). Chlorogenic acid was quantified only in Sample 1 (3.34 mg/100 g). Hyperoside, a flavonoid glycoside, was quantified in all six samples, with higher values in Samples 4 and 1 (20.28 and $15.43 \mathrm{mg} / 100 \mathrm{~g}$ ); its concentration decreases as follows: Sample $4>1>3>6>5>2$. Close values were found in the pairs of Samples 2 and 5 and Samples 3 and 6. Rutin was determined in two samples, 1 and 3, with a higher value in Sample 1 (14.51 mg/100 g). Isoquercitrin and quercitrin were quantified in samples 
$2,4,5,6$. Both glycosides presented higher values in Sample 6 (14.81 mg/100 g for isoquercitrin and 6.94 $\mathrm{mg} / 100 \mathrm{~g}$ for quercitrin). Luteolin was the only flavonoid aglycone identified in all 6 samples reaching a high in Sample 2 (23.07 mg/100 g). Quercetin was detected in high quantity in Sample $3(101.42 \pm 2.02$ $\mathrm{mg} / 100 \mathrm{~g}$ ), kaempferol was present in high quantity in Sample 6 (12.77 mg/100 g), but it was absent in Sample 1, and apigenin was found in the samples 1, 3, 5 , with a high value in Sample 3 (2.34 mg/100 g). The analysis of the 6 commercial teas revealed moderate antioxidant properties, due to the presence of polyphenol compounds. Sample 6 presents the higher TPC (6.79 g/100 g), the higher TFC (1.169 g/100 g), and the better antioxidant capacity $\left(\mathrm{IC}_{50}=56.431\right)$, in accordance with the content of polyphenols. The obtained results showed qualitative and quantitative differences between the commercial samples; that's why the quality of the raw material is very important, in order to obtain a good quality product.

\section{Conclusions}

The study conducted on 6 Rooibos tea assortments available on Romanian market revealed a good polyphenol composition with a moderate antioxidant capacity. The differences between the studied samples were both quantitative and qualitative. The polyphenols identified in all six samples were ferulic acid, synapic acid, hyperoside and luteolin, while quercitrin and isoquercitrin were present in 4 samples and rutin only in 2 samples. Our analysis confirmed the presence of antioxidant polyphenols in the Rooibos commercial teas, and highlighted the differences determined by the quality of the raw materials.

\section{Acknowledgement}

The authors would like to thank the "Iuliu Hațieganu" University of Medicine and Pharmacy of Cluj-Napoca for the financial support (project Alexandra Epure, nr. 1680/40/19.01.2018).

\section{References}

1. Benedec D, Hanganu D, Filip L, Oniga I, Tiperciuc B, Olah NK, Gheldiu AM, Raita O, Vlase L, Chemical, antioxidant and antibacterial studies of Romanian Heracleum sphondylium. Farmacia, 2017; 65(2): 252-256.

2. Hawkins HJ, Malgas R, Biénabe E, Ecotypes of wild Rooibos (Aspalathus linearis (Burm. F) Dahlg., Fabaceae) are ecologically distinct. S Afr J Bot., 2011; 77: 360-370.

3. Ielciu I, Vlase L, Frederich M, Hanganu D, Paltinean R, Cieckiewicz E, Olah NK, Gheldiu AM, Crişan G,
Polyphenolic profile and biological activities of the leaves and aerial parts of Echinocystis lobata (Michx.) Torr. et A. Gray (Cucurbitaceae). Farmacia, 2017; 65(2): 179-183.

4. Ivanescu B, Tuchiluș C, Corciovă A, Apetrei CC, Mihai T, Gheldiu AM, Vlase L, Antioxidant, antimicrobial and cytotoxic activity of Tanacetum vulgare, Tanacetum Corymbosum and Tanacetum macrophyllum extracts. Farmacia, 2018; 66(2): 282-288.

5. Joubert E, De Beer D, Rooibos (Aspalathus linearis) beyond the farm gate: From herbal tea to potential phytopharmaceutical. S Afr J Bot., 2011; 77: 869-886.

6. Joubert E, Gelderblom W C, Louw A, De Beer D, South African herbal teas: Aspalathus linearis, Cyclopia spp. and Athrixia phylicoides - a review. J Ethnopharmacol., 2008; 119(3): 376-412.

7. Koch IS, Muller M, Joubert E, van der Rijst M, Næs T, Sensory characterization of Rooibos tea and the development of a Rooibos sensory wheel and lexicon. Food Res Int., 2012; 46(1): 217-228.

8. Kotina EL, Stepanova AV, Tilney PM, Van Wyk $\mathrm{BE}$, The pharmacognostic value of leaf and stem anatomy in Rooibos tea (Aspalathus linearis). S Afr J Bot., 2012; 82: 129-133.

9. Leucuta S, Vlase L, Gocan S, Radu L, Fodorea C, Determination of phenolic compounds from Geranium sanguineum by HPLC. J Liq Chromatogr Relat Technol., 2005; 28(19): 3109-3117.

10. McAlpine M, Ward WE, Influence of steep time on polyphenol content and antioxidant capacity of Black, Green, Rooibos and herbal teas. Beverages, 2016; 2(3): 1-17.

11. Oniga I, Toiu A, Benedec D, Tomuță I, Vlase L, Phytochemical analysis of Hypericum maculatum in order to obtain standardized extracts. Farmacia, 2016; 64(2): 171-174.

12. Oniga I, Puscas C, Silaghi-Dumitrescu R, Olah NK, Sevastre B, Marica R, Marcus I, Sevastre-Berghian AC, Benedec D, Pop CE, Hanganu D, Origanum vulgare ssp. vulgare: chemical composition and biological studies. Molecules, 2018; 23(8): 2077: 1-14.

13. Orodan M, Vodnar D, Toiu A, Pop C, Vlase L, Viorica I, Arsene A, Phytochemical analysis, antimicrobial and antioxidant effect of some gemmotherapic remedies used in respiratory diseases. Farmacia, 2016; 64(2): 224-230.

14. Thaipong K, Boonprakob U, Crosby K, CisnerosZevallos L, Hawkins Byrne D, Comparison of ABTS, DPPH, FRAP, and ORAC assays for estimating antioxidant activity from guava fruit extracts. $J$ Food Compos Anal., 2006; 19: 669-675.

15. Vlase L, Mocan A, Hanganu D, Benedec D, Gheldiu A, Crișan G, Comparative study of polyphenolic content, antioxidant and antimicrobial activity of four Gallium species (Rubiaceae). Dig J Nanomater Biostruct., 2014; 9(3): 1085-1094. 